\title{
Penerapan Metode Demonstrasi untuk Meningkatkan Hasil Belajar Siswa pada Mata Pelajaran Informatika Materi Operasi Dasar Komputer di SMAN 4 Kota Bima Kelas X MIPA 1 Semester Ganjil Tahun Pelajaran 2020/2021
}

\author{
Ruwaidah \\ SMA Negeri 4 Kota Bima, Kota Bima, Indonesia \\ *Coresponding Author : ruwaidah302@gmail.com \\ Dikirim: 19-08-2021; Direvisi: 24-10-2021; Diterima: 25-10-2021
}

\begin{abstract}
Abstrak: Penelitian ini mengangkat masalah keadaan awal keterampilan siswa di kelas $\mathrm{X}$ MIPA.1 SMAN 4 Kota Bima pada mata pelajaran Informatika materi operasi dasar komputer yang masih kurang memuaskan dengan penggunaan metode pembelajaran dimana proses pembelajaran masih berpusat pada guru dan pemberian tugas. Jenis penelitian yang digunakan adalah penelitian tindakan kelas yang terdiri dari dua siklus, dilakukan dua siklus karena target hasil belajar yang dicapai sudah dapat terlaksana pada siklus dua. Setiap siklusnya terdiri atas perencanaan, pelaksanaan, observasi, dan refleksi. Masalah penelitian ini adalah bagaimana Penerapan metode demonstrasi dapat meningkatkan hasil belajar siswa pada mata pelajaran Informatika materi operasi dasar komputer semester I di Kelas X MIPA.1 SMAN 4 Kota Bima Tahun Pelajaran 2020/2021? Hasil penelitian telah berhasil mendeskripsikan penerapan dengan menggunakan metode pembelajaran "Demonstrasi" dapat meningkatkan hasil belajar siswa pada mata pelajaran Informatika materi operasi dasar kompueter semester I di kelas X MIPA.1 SMAN 4 Kota Bima tahun pelajaran 2020/2021. Hal ini terlihat pada peningkatan aktivitas siswa pada proses pembelajaran serta peningkatan hasil belajar siswa pada mata pelajaran informatika materi operasi dasar komputer yang ditugaskan oleh guru setiap siklusnya. Peningkatan aktivitas siswa terlihat sebagai berikut: pada siklus I rata-rata dari jumlah seluruh aspek yang diamati adalah 53,7\%, pada siklus II jumlah rata-rata meningkat menjadi $80.0 \%$. Sedangkan peningkatan hasil belajar siswa yang terlihat pada ketuntasan siswa dalam menyelesaikan cara mengoperasikan komputer sebagai berikut : sebelumnya tanpa menggunakan metode demonstrasi siswa yang tuntas 10 orang $(33,3 \%)$ dan setelah menggunakan metode demonstrasi pada siklus I jumlah siswa yang tuntas 16 orang $(53,3 \%)$, dan pada siklus II jumlah siswa yang tuntas mencapai 28 orang $(93,3 \%)$.
\end{abstract}

Kata Kunci: hasil belajar; metode demonstrasi

Abstract: This study raises the problem of the initial state of student skills in class $\mathrm{X}$ MIPA.1 SMAN 4 Kota Bima in the subject of Informatics subject matter of basic computer operations which are still unsatisfactory with the use of learning methods where the learning process is still teacher-centered and assigning assignments. The type of research used is classroom action research which consists of two cycles, carried out in two cycles because the learning outcomes achieved can already be implemented in cycle two. Each cycle consists of planning, implementation, observation, and reflection. The problem of this research is how the application of the demonstration method can improve student learning outcomes in the Informatics subject for the first semester of basic computer operations in Class X MIPA.1 SMAN 4 Kota Bima in the 2020/2021 academic year? The results of the study have succeeded in describing the application of using the "Demonstration" learning method to improve student learning outcomes in Informatics subjects, basic computer operations in the first semester of class X MIPA.1 SMAN 4 Kota Bima in the academic year 2020/2021. This can be seen in the increase in student activity in the learning process as well as the increase 
in student learning outcomes in informatics subjects with basic computer operations assigned by the teacher each cycle. The increase in student activity can be seen as follows: in the first cycle the average number of all aspects observed was 53.7\%, in the second cycle the average number increased to $80.0 \%$. While the increase in student learning outcomes seen in the mastery of students in completing how to operate a computer as follows: previously without using the demonstration method, 10 students completed (33.3\%) and after using the demonstration method in the first cycle, 16 students completed (53).,3\%), and in the second cycle the number of students who completed reached 28 people $(93.3 \%)$.

Keywords: learning outcomes; demonstration method

\section{PENDAHULUAN}

Dewasa ini, pemanfaatan TIK sebagai alat pembelajaran dalam dunia pendidikan tidaklah cukup karena saat ini dunia global telah memasuki era revolusi industri generasi keempat atau Revolusi Industri 4.0 (Industrial Revolution 4.0/IR 4.0) yang tidak dapat dihindari oleh bangsa Indonesia.

Mata pelajaran Informatika diharapkan menumbuhkembangkan siswa menjadi "computationally literate creators" yang menguasai konsep dan praktik informatika berikut. 1. Berpikir komputasional 2. Memahami ilmu pengetahuan yang mendasari Informatika. 3. Terampil berkarya untuk dalam menghasilkan artefak komputasional sederhana dengan memanfaatkan teknologi dan menerapkan proses rekayasa, serta mengintegrasikan pengetahuan bidang-bidang lain yang membentuk solusi sistemik. 4. Terampil dalam mengakses, mengelola, menginterpretasi, mengintegrasikan, dan mengevaluasi informasi, serta menciptakan informasi baru dari himpunan data dan informasi yang dikelolanya, dengan memanfaatkan teknologi informasi dan komunikasi TIK yang sesuai. 5. Menunjukkan karakter baik sebagai anggota masyarakat digital sehingga berkomunikasi, berkolaborasi, berkreasi, dan menggunakan perangkat teknologi informasi disertai kepedulian terhadap dampaknya dalam kehidupan bermasyarakat (Wahyono, 2021)

Tidak mudah bagi guru untuk dapat mewujudkan siswa yang terampil dalam mengakses, mengelola, menginterpretasi, mengintegrasikan, dan mengevaluasi informasi, serta menciptakan informasi baru dari himpunan data dan informasi yang dikelolanya, dengan memanfaatkan teknologi informasi dan komunikasi TIK yang sesuai.

Dalam Kurikulum 2013 pendekatan pembelajaran yang dilakukan menekankan pentingnya pendekatan saintifik atau pendekatan proses keilmuan melalui tahapan proses pembelajaran: (1) mengamati; (2) menanya; (3) mengumpulkan informasi; (4) menalar atau mengasosiasi ; dan (5) mengomunikasikan. (Kemdikbud, 2014).

Terampil dalam mengakses, mengelola, menginterpretasi, mengintegrasikan, dan mengevaluasi informasi, serta menciptakan informasi baru maka dalam proses pelaksanaan pembelajaran perlu dilakukan dengan menggunakan metode yang efektif. Pada pembelajaran informatika pra sikus kelas X MIPA.1 SMAN 4 Kota Bima materi materi operasi dasar komputer peneliti melakukan pembelajaran dengan menggunakan metode peer teaching, tutor sebaya dengan pertimbangan sebagian siswa telah mampu melakukan operasi dasar komputer. Hasil ppembelajaran pra siklus tidak seperti yang diharapkan dimana hasil belajar siswa rendah. Ketuntasan siswa 33\% dengan rata-rata nilai siswa $60,07 \%$. 
Belajar dari hasil refleksi pra siklus peneliti mencoba menerapkan metode demonstrasi pada siswa. "Demonstrasi adalah cara mengajar dimana seorang guru menunjukkan atau memperlihatkan suatu proses" (Roestyah,N.K, 1991). metode ini adalah metode yang mempraktikkan langsung langkah-langkah pengerjakan sesuatu dalam hal ini peneliti mendemonstrasikan langkah-langkah pada materi operasi dasar komputer. Dengan demikian, diharapkan siswa kelas X MIPA.1 SMAN 4 Kota Bima dapat mengerti secara langsung bagaimana teknik pengerjaannya, kemudian siswa diberkan kesemppatan untuk mempraktekkannya seperti yang didemonstrasikan guru. Diharapkan dengan metode demonstrasi ini siswa lebih mudah memahami teknis pengerjaannya, serta mendorong semangat untuk aktif berkarya. Pada akhirnya keaktifan siswa dalam belajar ini akan dapat meningkatkan hasil belajarnya.

\section{KAJIAN TEORI}

\section{Hakikat Belajar}

Belajar adalah perkembangan yang berasal dari latihan dan usaha (Soeparwoto dkk 2007: 34). Belajar dapat terjadi melalui dua cara yaitu imitasi dan identifikasi. Imitasi artinya individu meniru yang dilakukan orang lain. Sedangkan identifikasi artinya individu menerima sikap, nilai, motivasi, dan perilaku orang yang dihormati atau dicintai. Gagne dan Berliner dalam Anni dkk (2007:2) mendefinisikan belajar merupakan proses dimana suatu organisme mengubah perilakunya karena hasil dari pengalaman.

Pengertian belajar menurut Slameto (2010: 2) adalah suatu proses usaha yang dilakukan seseorang untuk memperoleh suatu perubahan tingkah laku yang baru secara keseluruhan, sebagai hasil pengalamannya sendiri dalam interaksi dengan lingkungannya. Berdasarkan beberapa pengertian belajar, maka dapat disimpulkan bahwa belajar merupakan suatu proses perubahan sikap dan tingkah laku yang bersifat permanen yang disebabkan karena adanya pengaruh pengalaman dan lingkungan.

\section{Hakikat Aktivitas Belajar}

Menurut Sardiman dalam Saminanto (2010: 97) aktivitas belajar adalah keaktifan yang bersifat fisik maupun mental. Dalam proses pembelajaran keduanya harus saling menunjang agar diperoleh hasil belajar yang optimal.

Menurut Poerwadarminta dalam Yusfy (2011), aktivitas adalah kegiatan, sehingga aktivitas belajar adalah kegiatan-kegiatan siswa yang menunjang keberhasilan belajar. Slameto (2010: 36) berpendapat mengenai proses belajar mengajar bahwa dalam proses belajar mengajar, guru perlu menimbulkan aktivitas siswa dalam berpikir maupun berbuat. Aktivitas yang dilakukan siswa dalam proses pembelajaran tersebut akan meninggalkan kesan. Siswa tidak akan menghilangkan kesan tersebut begitu saja, tetapi dipikirkan, diolah, kemudian dikeluarkan lagi dalam bentuk yang berbeda.

Merujuk pendapat Dierich dalam Hamalik (2011: 172-3) ada delapan kelompok aktivitas belajar, yaitu: 
1. Kegiatan-kegiatan visual, meliputi membaca, melihat gambar-gambar, mengamati, eksperimen, demonstrasi, pameran, dan mengamati orang lain bekerja atau bermain.

2. Kegiatan-kegiatan lisan (oral), meliputi mengemukakan suatu fakta atau prinsip, menghubungkan suatu kejadian, mengajukan pertanyaan, memberi saran, mengemukakan pendapat, wawancara, diskusi, dan interupsi.

3. Kegiatan kegiatan mendengarkan, meliputi mendengarkan penyajian bahan, percakapan atau diskusi kelompok, permainan, dan radio.

4. Kegiatan-kegiatan menulis, meliputi menulis cerita, laporan, memeriksa karangan, membuat rangkuman, mengerjakan tes, dan mengisi angket.

5. Kegiatan-kegiatan menggambar, meliputi menggambar, membuat grafik, chart, diagram peta, dan pola.

6. Kegiatan-kegiatan metrik, meliputi melakukan percobaan, memilih alat-alat, melaksanakan pameran, membuat model, menari, berkebun, dan menyelenggarakan permainan.

7. Kegiatan-kegiatan mental, meliputi merenungkan, mengingat, memecahkan masalah, menganalisis faktor-faktor, melihat hubunganhubungan, dan membuat keputusan.

8. Kegiatan-kegiatan emosional, meliputi minat, membedakan, berani, tenang, dan lain-lain.

Berdasarkan beberapa pengertian aktivitas yang telah dipaparkan, maka peneliti dapat menyimpulkan bahwa aktivitas belajar adalah segala kegiatan yang dilakukan siswa selama proses pembelajaran baik yang bersifat fisik maupun mental dan akan berpengaruh pada hasil belajar. Jadi, hasil belajar yang diperoleh siswa sangat bergantung pada bagaimana aktivitas belajar yang dilakukan selama pembelajaran.

\section{Hakikat Hasil belajar}

Hasil belajar merupakan perubahan perilaku yang diperoleh pembelajar setelah mengalami aktivitas belajar (Anni dkk 2007: 5). Menurut Suprijono (2011:5), hasil belajar adalah pola-pola perbuatan, nilai-nilai, pengertianpengertian, sikap-sikap, apresiasi, dan keterampilan. Hasil belajar menurut Bloom dalam Rifa'i dan Anni (2009: 86) digolongkan menjadi tiga domain, yaitu domain kognitif, afektif dan psikomotor. Domain kognitif berkenaan dengan pengembangan kemampuan otak dan penalaran siswa. Domain afektif berkenaan dengan sikap dan nilai. Domain psikomotor tampak dalam bentuk keterampilan dan kemampuan siswa dalam bertindak.

Menurut Gagne dan Briggs dalam Anni dkk (2007:12) mengklasifikasikan hasil belajar dalam lima kategori, yaitu: (1) kemahiran intelektual; (2) strategi kognitif ; (3) informasi verbal ; (4) kemahiran motorik ; dan (5) sikap. Berdasarkan paparan mengenai pengertian hasil belajar, maka dapat disimpulkan bahwa hasil belajar merupakan kemampuan yang dimiliki seseorang setelah mengalami proses belajar, baik yang bersifat langsung maupun tidak langsung (dampak pengiring). Hasil belajar akan lebih bermakna apabila proses pelaksanaannya menyenangkan dan terjadi penguatan. 


\section{Hakikat Pembelajaran}

Undang-Undang No 20 tahun 2003 tentang Sistem Pendidikan Nasional Bab I Pasal 1 ayat 20 menjelaskan bahwa pengertian pembelajaran adalah proses interaksi peserta didik dengan pendidik dan sumber belajar pada suatu lingkungan belajar. Pembelajaran menurut Briggs dalam Sugandi (2007: 9) adalah seperangkat peristiwa yang mempengaruhi si belajar sedemikian rupa, sehingga memperoleh kemudahan dalam berinteraksi berikutnya dengan lingkungan.

Menurut Isjoni (2010:11) pembelajaran pada dasarnya merupakan upaya pendidik untuk membantu peserta didik melakukan kegiatan belajar. Menurut Siddiq dkk (2009: 1-9) pembelajaran adalah suatu upaya yang dilakukan oleh seseorang (guru atau yang lain) untuk membelajarkan siswa yang belajar. Pada pendidikan formal (sekolah), pembelajaran merupakan tugas yang dibebankan kepada guru, karena guru merupakan tenaga profesional yang dipersiapkan untuk itu.

Dari beberapa pengertian pembelajaran, maka peneliti dapat menyimpulkan pengertian pembelajaran adalah seperangkat peristiwa berupa interaksi siswa dengan pendidik dan sumber belajar lainnya untuk mencapai hasil belajar yang telah ditentukan pada suatu lingkungan belajar

\section{Metode Demonstrasi}

Metode demonstrasi merupakan metode mengajar yang sangat efektif untuk membantu siswa dalam mencari jawaban atas pertanyaan-pertanyaan seperti: bagaimana cara membuatnya? Terdiri dari bahan apa? Bagaimana cara mengaturnya? Bagaimana proses bekerjanya?. Setiap mata pelajaran dalam proses belajar mengajar, sering kali guru hanya memakai metode ceramah dan diskusi.

Banyak pendapat ahli tentang pengertian metode demonstrasi antara lain : A.Tabrani Rusyan (1993 : 106) mengatakan bahwa "Metode Demonstrasi adalah merupakan pertunjukan tentang proses terjadinya suatu peristiwa atau benda sampai pada penampilan tingkah laku yang dicontohkan".

"Demonstrasi adalah cara mengajar dimana seorang guru menunjukkan atau memperlihatkan suatu proses" (Roestyah,N.K, $1991: 83$ ).

Sehubungan dengan pengertian di atas dapat dinyatakan bahwa metode demonstrasi adalah menunjukkan proses terjadinya sesuatu, agar pemahaman siswa terhadap pelajaran akan lebih berkesan secara mendalam sehingga membentuk pengertian dengan baik dan sempurna serta hasil belajar yang lebih baik. Karena itu, demonstrasi dapat dibagi menjadi dua tujuan (Morgan et al dalam buku Suprijanto 2008:143):

a. Demonstrasi Cara

Menunjukkan bagaimana mengerjakan sesuatu, ini termasuk bahanbahan yang digunakan dalam pekerjaan yang sedang diajarkan, memperlihatkan apa yang dikerjakan dan bagaimana mengerjakannya, serta menjelaskan setiap langkah mengerjakannya.

b. Demonstrasi Hasil

Menunjukkan hasil dari beberapa praktik dengan menggunakan buktibukti yang dapat dilihat, didengar, dan dirasakan. 


\section{Langkah-langkah Metode Demonstrasi}

Metode demonstrasi memiliki cara atau langkah-langkah kerja dalam penerapannya dalam sebuah pembelajaran di sekolah. Adapun langkah-langkah metode demonstrasi tersebut adalah sebagai berikut :

a. Mempersiapkan alat dan bahan bantu yang akan digunakan dalam pembelajaran.

b. Memberikan penjelasan tentang topik yang akan didemonstrasikan

c. Pelaksanaan demonstrasi bersamaan dengan perhatian dan peniruan dari siswa. Memperagakan tindakan, proses, atau prosedur yang disertai penjelasan tentang prosedur, ilustrasi dan pertanyaan.

d. Penguatan (diskusi, tanya jawab, dan atau latihan) terhadap hasil demonstrasi.

e. Evaluasi hasil belajar dan kesimpulan

Setiap pembelajaran perlu penerapan langkah yang tepat, baik adalam memilih metode dan media pembelajaran. Menurut H.E. Mulyasa (2009:188) Penerapan dalam pembelajaran dapat dilakukan dengan cara berikut :

1. Mengembangkan keberanian dan rasa percaya diri siswa serta mengurangi perasaan yang kurang menyenangkan.

2. Memberi kesempatan kepada seluruh siswa untuk berkomunikasi secara aktif dan terarah.

3. Melibatkan siswa dalam menentukan tujuan belajar dan penilaian hasil belajar.

4. Memberikan pengawasan yang tidak terlalu ketat dan tidak otoriter.

5. Melibatkan siswa secara aktif, kreatif, efektif, dan menyenangkan dalam proses pembelajaran secara keseluruhan.

Pada dasarnya semua metode pembelajaran baik, tidak ada yang paling baik dan paling efektif, hal ini tergantung bagaimana cara guru menggunakannya dan menempatkannya sesuai dengan materi yang diajarkan. Dan memperhatikan kelemahan serta kelebihan pada metode yang dipakai. Penggunaan metode demonstrasi ini juga, menghindari pengajaran yang bersifat individualisme (tertuju hanya pada seorang saja) dan verbalisme (pengungkapan lewat kata-kata untuk mengungkapkan gagasan atau pengertian) (Mangunhardjana, 1997:232)

\section{Pembelajaran Informatika di SMA}

Kurikulum 2013 dikembangkan dengan memerhatikan faktor-faktor yang bersifat internal dan eksternal. Faktor yang bersifat internal terkait dengan aspek teknis pengembangan kurikulum, sedangkan faktor eksternal antara lain terkait kebijakan pemerintah yang ditetapkan melalui berbagai produk hukum seperti Peraturan Pemerintah, Keputusan Presiden, Peraturan Menteri, dan peraturan di bawahnya. Faktor eksternal lainnya adalah perubahan-perubahan yang terjadi di masyarakat dalam berbagai aspek kehidupan sosial, budaya, ekonomi, ilmu pengetahuan, teknologi, politik, dan hubungan antar bangsa yang semakin terbuka sebagai akibat globalisasi dan perkembangan pesat teknologi informasi dan komunikasi (TIK). Pada jenjang SMA/MA, peserta didik mempelajari aspek keilmuan informatika yang lebih abstrak secara lebih mendalam, kemudian secara kreatif menerapkannya menjadi produk digital dan aspek sosial, dengan menerapkan STEM, mengintegrasikan antar sub-area pengetahuan informatika, ataupun dengan bidang lainnya. 
Proses pembelajaran lnformatika diharapkan untuk dilaksanakan melalui berbagai aktivitas yang dapat menumbuhkan kemampuan berpikir kritis, kreatif, komunikasi, dan kolaborasi sebagai mana diharapkan sebagai ciri utama kemampuan abad ke-21. Selain itu, melalui proses belajar yang menyenangkan dan bermakna, peserta didik akan bertumbuh untuk memenuhi standar peserta didik yang menjadi pembelajar berdaya, warga digital yang baik, konstruktor pengetahuan, perancang yang inovatif, pemikir komputasional, kolaborator global, dan komunikator yang kreatif.

Pada SMA/MA, mapel lnformatika dapat diberikan secara terstruktur melalui mapel pilihan pada kelompok C (peminatan akademik). Dengan terbitnya Peraturan Menteri Pendidikan dan Kebudayaan Republik Indonesia Nomor 36 Tahun 2018 tentang Perubahan atas Peraturan Menteri Pendidikan dan Kebudayaan Republik Indonesia Nomor 59 Tahun 2014 tentang Kurikulum 2013 Sekolah Menengah Atas/Madrasah Aliyah, Mapel Pilihan pada kelompok C (peminatan akademik) ditambah mapel Informatika, yang semula hanya terdapat mapel Lintas minat dan/atau mapel Pendalaman minat diubah menjadi mapel Lintas minat dan/atau mapel Pendalaman minat dan/atau mapel lnformatika. Pendekatan konvensional dengan modul teori-praktik kurang cocok untuk diterapkan. Secara natural, anak/peserta didik adalah pembelajar yang aktif ketimbang wadah yang hanya menerima materi belajar secara pasif. Jika peserta didik diberi kesempatan untuk mengeksplorasi, sedangkan guru mengambil posisi sebagai mentor dan fasilitator, maka proses belajar menjadi menyenangkan dan tidak membosankan. Pendekatan Activity-based Leaming (ABL), yang menjadikan pengalaman sebagai dasar proses belajar, perlu dilaksanakan. Peserta didik berlatih merajut potonganpotongan pengetahuan dari kegiatan (menonton video, eksperimen, bermain, mempertanyakan, diskusi dengan guru dan teman), untuk menjadi satu pengetahuan utuh yang terkonstruksi dengan baik.

Mapel lnformatika merupakan mapel pilihan yang diselenggarakan berdasarkan kondisi sekolah yang memerhatikan ketersediaan guru sesuai dengan kompetensi dan kualifikasi akademik, serta sarana/prasarana pada sekolah yang disajikan pada Bab III. Alokasi waktu untuk mapel lnformatika di Kelas X sebanyak 3 jp, sedangkan di Kelas XI dan XII masing-masing sebanyak 4 jp. Teknologi lnformasi dan Komunikasi pada Kurikulum 2013 dimanfaatkan sebagai alat pembelajaran (JCT for learning) yang terintegrasi pada semua mata pelajaran karena pada hakikatnya, saat ini semua kegiatan kehidupan termasuk pembelajaran, berbasis TIK. Untuk mewujudkannya warga sekolah seyogyanya memahami dan menerapkan TIK dalam pelaksanaan kegiatan di sekolah. Oleh karena itu, Menteri Pendidikan dan Kebudayaan Republik Indonesia telah mengatur peran guru TIK sebagaimana tertuang dalam Peraturan Menteri Pendidikan dan Kebudayaan Republik Indonesia Nomor 45 Tahun 2015 tentang Perubahan Atas Peraturan Menteri Pendidikan dan Kebudayaan Republik Indonesia Nomor 68 Tahun 2014 tentang Peran Guru Teknologi lnformasi dan Komunikasi dan Guru Keterampilan Komputer dan Pengelolaan lnformasi dalam lmplementasi Kurikulum 2013, yaitu membimbing peserta didik untuk mendukung kelancaran proses pembelajaran, memberikan layanan/fasilitasi kepada sesama guru untuk persiapan, pelaksanaan, dan penilaian pembelajaran dan memberikan layanan/fasilitasi kepada tenaga kependidikan untuk mengembangkan sistem manajemen sekolah berbasis TIK. 


\section{Perbedaan Antara TIK dan Informatika}

Muatan/mapel lnformatika merupakan perluasan dan pendalaman dari muatan TIK yang pada awal pemberlakuan Kurikulum 2013 yang penerapannya diintegrasikan kepada seluruh mapel melalui pembelajaran berbasis TIK. Perluasan dan pendalaman tersebut berdampak pada adanya perbedaan mendasar dari cakupan materi, proses pembelajaran, dan tujuan pembelajaran.

Kompetensi lnformatika tidak hanya menjadikan peserta didik sebagai pemakai (user) dan konsumer saja, melainkan lebih menekankan pada kemampuan mengidentifikasi persoalan-persoalan dan mengusulkan solusinya, kemudian secara kreatif dan inovatif menghasilkan produk-produk teknologi informasi sesuai dengan kaidah keilmuan informatika, rekayasa perangkat keras, perangkat lunak, dan pengolahan data dalam bentuk digital menjadi informasi. Kompetensi tersebut meliputi kecakapan digital yang diperlukan dalam kehidupan sehari-hari (life skill), pemanfaatan teknologi informasi, sampai dengan keilmuan informatika. Proses pembelajarannya dilakukan secara berjenjang, bertahap, dan berkelanjutan mulai dari SD/Ml, SMP/MTs, dan SMA/MA.

\section{Ruang Lingkup Informatika}

Muatan/mapel lnformatika berisi seperangkat $\mathrm{Kl}$ (kompetensi inti) dan KO (kompetensi dasar) yang dirancang untuk memberikan "bekal" keilmuan informatika kepada peserta didik jenjang pendidikan dasar dan menengah. Bekal yang dimaksud meliputi beberapa kemampuan sebagai berikut.

a) Berpikir, yaitu berpikir komputasional yang menjadi landasan dan prinsip pemecahan persoalan yang akan diselesaikan dengan bantuan komputer.

b) Berkarya dan terampil, yaitu kemampuan dalam menggunakan dan menghasilkan produk TIK serta berkomunikasi dan berkolaborasi di dunia digital dengan memanfaatkan sarana TIK.

c) Berpengetahuan, yaitu kemampuan tentang keilmuan informatika yang mencakup lima area pengetahuan informatika yaitu Teknik Komputer, Jaringan Komputer/Internet, Analisis Data, Algoritme, dan Pemrograman, dan Dampak Sosial lnformatika.

d) Berkarakter, yaitu berkemampuan dalam mendayagunakan teknologi untuk menunjang kehidupan dan berkomunikasi

\section{Implementasi Kurikulum Informatika}

\section{a) Perancangan Pembelajaran}

Secara rinci, langkah yang dilakukan dalam merancang implementasi muatan lnformatika yang dilakukan dalam kelompok adalah sebagai berikut.

1) Guru mempelajari dan memahami kurikulum untuk tingkatan yang akan diselenggarakan (SD, SMP, SMA) dan model silabus yang sudah dirumuskan oleh Kemendikbud dan dapat diakses pada http://litbang.kemdikbud.go.id. Setiap anggota tim harus mempelajari dan memahami materi ajar dengan membaca buku teks terkait dan mulai memikirkan metode yang cocok untuk mendukung proses pembelajaran. Pemahaman diwujudkan dalam suatu bentuk peta konsep pengetahuan yang utuh untuk satu tahun, yang distrukturkan berdasarkan model silabus, menjadi unit pembelajaran dan capaian kompetensinya. 
2) Guru mengidentifikasi sarana yang diperlukan: buku, perangkat, fasilitas lain, untuk memberikan arahan apakah pelaksanaan lebih banyak dilakukan dengan menggunakan perangkat TIK, atau tanpa perangkat (unplugged).

3) Guru perancang kurikulum menyusun peta konsep secara keseluruhan untuk satu tahun dan silabus berdasarkan model silabus, yang akan diterapkan di sekolahnya.

4) Guru perancang kurikulum menyusun drat rencana pembelajaran tahunan (prota) dan semesteran (prosem), model pembelajaran yang akan dilakukan, dan contoh-contoh untuk dikembangkan oleh guru, antara lain: contoh materi, soal ujian, dan rubrik penilaian.

5) Guru mengidentifikasi resources untuk mendapatkan materi-materi ajar.

6) Berdasarkan langkah (1) s.d. (5) di atas, tim menghasilkan drat dokumen peta konsep, prota, prosem, silabus, dan RPP.

7) Drat dokumen pada langkah (6) dibahas dan direview oleh tim ahli materi untuk mendapatkan perangkat pembelajaran yang cukup berbobot keilmuan dan sesuai aspek pedagoginya.

8) Drat dokumen peta konsep, prota, prosem, dan silabus yang dihasilkan pada langkah (7) disahkan oleh Kepala Sekolah, menjadi dasar pengembangan RPP.

9) Bermodalkan pada dokumen yang sudah disahkan pada langkah (8), untuk setiap unit pembelajaran, setiap guru pengajar mengembangkan RPP secara lebih rinci dengan format yang sudah ditentukan oleh sekolah. RPP Final harus sesuai dengan kaidah yang sudah ditentukan dalam Permendikbud Nomor 22 Tahun 2016 tentang Standar Proses Pendidikan Dasar dan Menengah dan sesuai dengan format yang ditetapkan oleh sekolah.

\section{b) Pelaksanaan}

Pada tahap pelaksanaan pembelajaran, proses pembelajaran dijalankan dengan mengacu prosem dan RPP final dengan menggunakan bahan ajar yang sudah dikembangkan. Sesuai dengan praktik pelaksanaan semester, pelaksanaan dalam satu semester dibagi menjadi dua bagian dan akan dievaluasi menjadi dua tahap, yaitu evaluasi setelah Penilaian Tenganh Semester (PTS) dan evaluasi setelah Penilaian Akhir Semester (PAS).

Untuk periode satu semester, kesesuaian RPP dengan materi ajar yang dikembangkan, serta ketercapaian indikator perlu diukur oleh guru, minimal dalam dua tahap yaitu setelah PTS dan setelah dan PAS.

\section{c) Evaluasi}

Setelah proses pelaksanaan selesai dilakukan, Kepala Sekolah melakukan proses evaluasi terhadap pelaksanaan proses pembelajaran. Evaluasi dilakukan terhadap semua perangkat pembelajaran dalam repositori dan dapat dilengkapi dengan kuesioner atau wawancara baik ke guru atau murid jika diperlukan. Hasil dari proses evaluasi adalah rekomendasi perbaikan bagi pelaksanaan pembelajaran tahun berikutnya.

\section{METODE PENELITIAN}

\section{Lokasi Penelitian}

Penelitian tindakan kelas ini dilaksanakan di SMAN 4 Kota Bima untuk mata pelajaran Seni Budaya dan Keterampilan kelas X MIPA.1. 


\section{Waktu Penelitian}

Penelitian ini telah dilaksanakan pada semester I/Semester ganjil Tahun Pelajaran 2020/2021 bulan September sampai dengan Oktober 2020. PTK ini dilaksanakan melalui dua siklus untuk melihat peningkatan hasil belajar dan aktivitas siswa dalam mengikuti mata pelajaran seni budaya dan keterampilan melalui pembelajaran metode demonstrasi.

\section{Subjek Penelitian}

Dalam penelitian ini yang menjadi subjek penelitian adalah siswa kelas $X$ MIPA. 1 yang terdiri dari 30 siswa terdiri dari 15 siswa perempuan dan 15 siswa lakilaki.

\section{Teknik dan Alat Pengumpulan Data}

a. Teknik

Dalam penelitian ini terdapat teknik dan alat pengumpulan antara lain :

Tes

: dipergunakan untuk mendapatkan data tentang hasil belajar siswa.

Observasi $\quad:$ dipergunakan untuk mengumpulkan data tentang aktivitas siswa dalam proses belajar mengajar.

Dokumentasi : dipergunakan untuk mendapatkan data berupa gambar dari aktivitas belajar dan hasil akhir karya.

b. Alat Pengumpulan Data

Tugas praktik karya kerajinan untuk mengukur hasil belajar siswa. Lembar observasi untuk melihat aktivitas siswa dalam proses belajar mengajar seni budaya dan keterampilan. Kamera digital untuk mendapatkan gambar aktivitas siswa dan hasil karya siswa.

\section{Teknik Analisis Data}

Data yang dikumpulkan pada setiap kegiatan observasi dari pelaksanaan siklus penelitian dianalisis secara deskriptif dengan menggunakan teknik persentase untuk melihat kecenderungan yang terjadi dalam kegiatan pembelajaran.

1. Hasil Belajar : dengan menganalisis kinerja siswa, Kemudian dikategorikan dalam klasifikasi tinggi (sangat baik), sedang (baik), dan rendah (cukup baik dan kurang baik).

2. Aktivitas siswa dalam proses belajar mengajar Informatika : dengan menganalisis tingkat keaktifan siswa dalam proses belajar mengajar Informatika. Kemudian dikategorikan dalam klasifikasi tinggi, sedang, dan rendah.

3. Penerapan pembelajaran metode demonstrasi : dengan menganalisis tingkat keberhasilan penerapan metode demonstrasi kemudian dikategorikan dalam klasifikasi berhasil, kurang berhasil, dan tidak berhasil.

Setelah data hasil pengamatan selama pembelajaran dan penilaian hasil praktik siswa dikumpulkan maka dilakukan analisis data. Yang menjadi indikator keberhasilan dalam penelitian ini antara lain : aktifitas siswa dalam kinerjanya melakukan operasi dasar komputer, dan hasil belajar siswa.

\section{Indikator Kinerja}

Penelitian ini dianggap berhasil apabila:

1. Prosentase ketuntasan hasil belajara siswa $\geq 75$ 
2. Rata-rata hasil belajar siswa $\geq 75$

\section{HASIL DAN PEMBAHASAN}

\section{Siklus I}

Guru mulai terbiasa menciptakan suasana pembelajaran yang mengarah kepada metode demonstrasi. Hal ini diperoleh dari hasil observasi terhadap aktivitas guru dalam mengajar menggunakan metode demonstrasi mencapai $65 \%$. Guru masih menggunakan metode ceramah oleh karena itu saat menggunakan metode demonstrasi guru berusaha menyesuaikan pembelajaran yang dibawakannya. Sebelum guru mengupayakan peningkatan aktivitas siswa, terlebih dahulu guru harus bisa menguasai metode dan materi pelajaran. Sehingga siswa akan lebih aktif jika yang mengajar ikut aktif dan bersemangat.

Dari lembar obervasi siswa, dikategorikan baik. Hasil observasi aktivitas siswa dalam pembelajaran mencapai 55\%. Setelah aktivitas guru meningkat, tentu saja aktivitas siswa sedikitnya mulai menunjukkan perkembangan ke arah yang lebih baik. Karena guru yang memberikan mendemostrasikan memberikan contoh terlebih tentang materi operasi dasar komputer dahulu kepada siswa, maka siswa akan mengikuti model pengajarnya tersebut. Semakin aktif guru dalam proses belajar besar kemungkinan mempengaruhi aktivitas siswa dalam belajar.

Dari $60 \%$ siswa yang mengikuti pembelajaran, masih ada yang belum dapat menyesuaikan waktu pada pengerjaan, karena belum terbiasa secara sistematik melakukan operasi dasar komputer. Mendapatkan pengalaman baru dalam mengoperasikan komputer seccara sistematik, tentunya akan membuat siswa makin bersemangat untuk bisa menyelesaikannya sebaik mungkin, ditambah kegiatan keterampilan ini menunjukkan proses belajar yang bebas, aktif, dan kreatif. Namun karena siswa terbiasa dengan pemberian tugas di rumah, maka mereka kurang mampu menyesuaikan waktu pelajaran, sehingga sebagian pekerjaan siswa belum dapat diselesaikan dengan baik. Hasil ketuntasan belajar siswa $74 \%$, dengan rata-rata hasil belajar 73 . Hasil ini sudah cukup baik dalam pelaksanaan pertemuan pertama, namun masih belum mencapai target indikator kinerja yang tditetapka yang diharapkan yaitu ketuntasan $75 \%$ dan rata-rata 75 .

\section{Siklus II}

Meningkatnya aktivitas siswa dalam proses belajar telah didukung oleh meningkatnya aktivitas guru dalam menciptakan susasana pembelajaran yang menyenangkan bebas, aktif, dan kreatif yang mengarah pada metode demonstrasi. Dapat dibandingkan pada hasil observasi siswa pada siklus pertama 55\%, menjadi $80 \%$ pada siklus kedua. Siswa mulai menjadi lebih aktif dalam belajar. Pembelajaran lebih mengarah ke pembelajaran yang aktif, dan kreatif dalam arti dapat mengerjakan tugas sesuai dengan keterampilan dan kemampuan yang mereka miliki, ditambah dengan bimbingan langsung dengan guru.

Aktivitas siswa dalam proses belajar mengajar sudah mengarah pada metode demonstrasi secara lebih baik. Siswa mulai mampu aktif dan kreatif dalam melaksanakan kegiatan keterampilan seni kolase dan mengerjakannya tepat waktu. Hasil refleksi pada siklus kedua ini, telah menunjukkan peningkatan yang cukup signifikan. Karenanya siswa telah mampu menyesuaikan waktu dengan 
pengerjakan tugas operasi dasar komputer yang diberikan kepada mereka. Tentunya siswa telah belajar dari pengalaman waktu siklus pertama.

Meningkatnya hasil kerja siswa pada materi operasi dasar komputer, karena guru secara intensif membimbing dan memperagakan metode kerja dengan efektif kepada siswa, terutama saat siswa mengalami kesulitan dalam proses belajar. Hal ini dapat dilihat dari hasil observasi guru pada siklus kedua meningkat dari 65\% pada siklus pertama, menjadi $85 \%$ pada siklus kedua. Hasil tugas keterampilan siswa materi operasi dasar komputer pada siklus kedua ini, mengalami perubahan. Siswa telah menguasai teknik dan bahan yang dipakai dibandingkan dengan siklus pertama. Hasil belajar yang diperoleh siswa dalam materi operasi dasar komputer yang dengan ketutasan klasikal 85\%, rata-rata 80. Perolehan ini sudah memenuhi indikator kinerja yang ditetapkan yang diharapkan yaitu ketuntasan klasikan $\geq 75 \%$, dengan rata-rata $\geq 75$. Karena hasil belajar yang dicapai sudah melampaui target maka kegiatan penelitian ini cukup pada pertemuan kedua.

\section{KESIMPULAN}

Setelah dilakukan penelitian terhadap sekolah SMAN 4 Kota Bima pada mata pelajaran Informatika dengan materi operasi dasar komputer, maka dapat disimpulkan penggunaan metode demonstrasi dapat meningkatkan hasil pada materi operasi dasar komputer. Hal ini dapat dilihat dari hasil pembelajaran sebagai berikut: 1) 1. Dari hasil observasi memperlihatkan bahwa terjadi peningkatan aktivitas siswa pada siklus I rata-rata 55\% menjadi $80 \%$ di siklus II. Hal ini karena guru terlibat langsung dalam proses belajar belajar, siswa jadi lebih bersemangat karena contoh karya dipraktikkan langsung oleh guru; dan 2) Meningkatnya hasil belajar siswa, dengan menggunakan metode demonstrasi dimana pada siklus II dengan ketutasan klasikal 85\%, rata-rata 80. Perolehan ini sudah memenuhi indikator kinerja yang ditetapkan yang diharapkan yaitu ketuntasan klasikan $\geq 75 \%$, dengan rata-rata $\geq 75$.

Pembelajaran metode demonstrasi pada mata pelajaran Informatika, bisa berjalan sesuai dengan perencanaan dan dapat dilaksanakan dengan baik serta meningkatkan hasil belajar siswa, maka hal yang dapat disarankan adalah sebagai berikut: 1) Dalam kegiatan belajar mengajar guru diharapkan menjadikan pembelajaran metode demonstrasi sebagai suatu alternatif dalam mata pelajaran Informatika khususnya dalam bidang praktik, untuk meningkatkan aktivitas serta hasil belajar siswa; 2) Guru yang mengajar pada mata pelajaran Informatika, merupakan guru yang memang berada pada bidang tersebut, sehingga tidak ada kesulitan bagi guru jika mempraktikan/mendemonstrasikan karya yang akan dikerjakan oleh siswa; dan 3) Karena kegiatan ini dapat bermanfaat bagi guru maupun siswa, maka sangat diharapkan agar kegiatan pembelajaran ini dapat dilakukan pada mata pelajaran praktik lainnya. Sekolah hendaknya dapat menyediakan sarana dan prasarana bagi siswa.

\section{DAFTAR PUSTAKA}

Agung, A. A. Gede, (1997). Pengantar Evaluasi Pengajaran. Singaraja : STKIP. 
Arikunto, Suharsimi. (2006). Prosedur Penelitian: Suatu Pendekatan Praktik. Jakarta: Rineka Cipta

Arikunto, Suharsimi. (2006). Penelitian Tindakan kelas. Jakarta : Bumi Aksara. Bahari, Nooryan. 2008. Kritik Seni. Yogyakarta: Pustaka Pelajar

DePorter, Bobbi \& Hernacki, Mike. (1992). Quantum Learning (Membiasakan Belajar Nyaman dan Menyenangkan).

Alwiyah Abdurrahman. (2003). Bandung : Kaifa Johnson, Elaine B. 2002. CTL (Contextual Teaching \& Learning). Bandung: Penerbit Kaifa.

Kamaril, Cut, dkk. (2002). Pendidikan Seni Rupa/Kerajinan Tangan. Jakarta: Pusat Penerbitan Universitas Terbuka.

Kunandar. (2010). Langkah Mudah Penelitian Tindakan kelas Sebagai Pengembangan Profesi Guru. Jakarta: PT Rajawali Pers

Malcolm C. Dorothea. (1972). Design Element and Principles. American : Davis Publication, Inc.

Mangunharjana A. (1997). Isme-isme Dalam Etika dari A Sampai Z. Yogjakarta: Kanisus

Muharam, dkk. (1991). Pendidikan Kesenian II Seni Rupa. Jakarta: Departemen Pendidikan dan Kebudayaan.

Mulyasa, H. E. (2009). Implementasi (KTSP) Kemandirian Guru \& Kepala Sekolah. Jakarta: Bumi Aksara

Munandar, Utami. (1999). Pengembangan kreativitas anak berbakat. Jakarta: Rineka Cipta.

Rachmawati dan Kurniati. (2010). Strategi Pengembangan Kreativitas Pada Anak. Jakarta : Kencana Prenada Media Group.

Rusman. (2011). Model-Model Pembelajaran. Jakarta: Rajawali Pers

Rusyan Tabrani, (1993). Proses Belajar Mengajar Yang Efektif tingkat Pendidikan Dasar. Bandung : Bina Budhaya.

Sagala, Syaiful. (2009). Konsep dan Makna Pembelajaran. Bandung : Penerbit Alfabet.

Sony, Dharsono. (2007). Kritik Seni. Bandung: Rekayasa Sains

Suharso \& Ana Retnoningsih. (2005). KBBI (Kamus Besar Bahasa Indonesia). Semarang : CV Widya Karya

Suprijanto. (2008). Pendidikan Orang Dewasa (Dari Teori Hingga Aplikasi). Jakarta : Bumi Aksara.

@2021 JPPI (https://jurnal.bimaberilmu.com/index.php/jppi) 